\title{
AKREDITASI SEKOLAH SEBAGAI SUATU UPAYA PENJAMINAN MUTU PENDIDIKAN DI INDONESIA
}

\author{
Aulia Ar Rakhman Awaludin \\ Program Studi Teknik Informatika, Universitas Indraprasta PGRI \\ email: aulia_awaludin@yahoo.co.id
}

\begin{abstract}
Abstrak
Kajian ini akan membahas upaya penjaminan mutu pendidikan di Indonesia melalui akreditasi sekolah. Metode yang digunakan di dalam penelitian ini adalah metode analisis kritis dan metode kepustakaan. Penjaminan mutu pendidikan adalah kegiatan sistemik dan terpadu oleh satuan atau program pendidikan, penyelenggara satuan atau program pendidikan, pemerintah daerah, pemerintah, dan masyarakat untuk menaikkan tingkat kecerdasan kehidupan bangsa melalui pendidikan. Akreditasi sekolah merupakan suatu proses penilaian secara komprehensif terhadap kelayakan suatu program pendidikan dengan mengacu Standar Nasional Pendidikan (SNP) yang dilakukan sebagai bentuk akuntabilitas publik. Akreditasi dilakukan melalui tindakan membandingkan kondisi sekolah dalam kenyataan dengan delapan kriteria (standar) yang telah ditetapkan. Dalam pelaksanaannya, pemenuhan dan pengembangan delapan standar secara berkelanjutan menyebabkan terselenggaranya pendidikan yang bermutu. Pelaksanaan akreditasi diharapkan dapat mendorong atau menciptakan suasana kondusif bagi pertumbuhan pendidikan dan memberikan arahan untuk evaluasi diri yang berkelanjutan, serta sebagai perangsang untuk terus berusaha mencapai mutu yang diharapkan, sehingga secara tidak langsung dapat menjamin mutu pendidikan.
\end{abstract}

Kata kunci: akreditasi sekolah, penjaminan mutu pendidikan

\begin{abstract}
This study will discuss the education quality assurance in Indonesia through school accreditation. The methods used in this study are critical analysis and library methods. Quality assurance in education is a systematic and integrated activity performed by an educational unit or program and its practitioners, local and central governments and community in an effort to raise the level of the nation's intelligence through education. School accreditation, a form of public accountability, is a comprehensive assessment of the feasibility of an educational program with reference to National Education Standards (SNP). Accreditation process is conducted by comparing the real condition of schools to the eight established criteria (standards). In practice, it is the sustainable application and development of these eight standards that lead to the quality education. The implementation of accreditation is expected to encourage or establish an atmosphere conducive to the educational development, to provide directions for conducting sustainable self-evaluation and to be an incentive to continuously achieve the desired quality that can indirectly assure the education quality.
\end{abstract}

Keywords: school accreditation, education quality assurance

\section{Pendahuluan}

Beberapa waktu yang lalu dunia pendidikan diramaikan dengan berita penghapusan Rintisan Sekolah Bertaraf Internasional (RSBI) di seluruh Indonesia, melalui pembatalan Pasal 50 ayat 3 Undang-Undang Nomor 20 tahun 2003 tentang Sisdiknas oleh MK pada hari Selasa, 8 Januari 2013. Penghapusan RSBI itu menimbulkan pro dan kontra. Di satu sisi RSBI dianggap sebagai sekolah favorit dengan kualitas yang bagus sehingga banyak orang tua berlomba-lomba menyekolahkan anaknya di RSBI. Di sisi lain RSBI dianggap tidak sejalan dengan UUD 1945 yang mengamanatkan bahwa semua warga negara berhak mendapatkan pendidikan, sementara yang bisa masuk RSBI kebanyakan anak orang-orang kaya atau 
kalangan menengah ke atas, dan mengakibatkan adanya diskriminasi serta kastanisasi pendidikan.

Adanya tanggapan pro dan kontra terhadap pembubaran RSBI itu menunjukkan bahwa sebagian besar masyarakat sadar akan pentingnya kualitas atau mutu pendidikan di Indonesia. Masyarakat menganggap bahwa pendidikan yang bermutu harus diupayakan dan selalu ditingkatkan, karena kualitas suatu negara dapat dilihat dari kualitas pendidikannya.

Sementara itu, berdasarkan data Education For All (EFA) Global Monitoring Report yang dilaksanakan oleh Organisasi Pendidikan, Ilmu Pengetahuan, dan Kebudayaan PBB (UNESCO) tahun 2012, Indonesia menduduki peringkat ke 64 dari 120 negara, sedangkan pada tahun sebelumnya menduduki peringkat ke-69 dari 127 negara. Kenyataan ini menunjukkan bahwa pendidikan di Indonesia masih ketinggalan dibandingkan negara-negara lain di dunia. Oleh karena itu, mutu atau kualitas pendidikan harus diupayakan untuk ditingkatkan agar mendekati atau sejajar dengan mutu pendidikan di negara lain.

Dalam Pembukaan Undang-undang Dasar 1945 disebutkan bahwa tujuan Negara Republik Indonesia di bidang pendidikan adalah untuk mencerdaskan kehidupan bangsa. Tujuan ini menuntut pemerintah untuk menyelenggarakan pendidikan yang bermutu. Mutu pendidikan di sini meliputi proses maupun hasil pendidikan. Dari sisi proses, pendidikan dikatakan bermutu apabila semua prosesnya berjalan dengan baik sesuai standar yang berlaku. Sedangkan dari sisi hasil, pendidikan dikatakan bermutu apabila hasil atau output dari suatu proses pendidikan yang dapat berupa nilai atau prestasi yang dicapai adalah nilai atau prestasi yang tinggi sesuai standar yang ditetapkan.

Di samping menyelenggarakan pendidikan yang bermutu, pemerintah juga harus menjamin mutu pendidikan mulai dari satuan pendidikan yaitu sekolah maupun madrasah. Artinya sekolah atau madrasah sebagai satuan pendidikan harus melaksanakan penjaminan mutu sebagai bentuk layanan terhadap masyarakat.

Yang menjadi pertanyaan sekarang adalah apakah penilaian masyarakat tentang mutu atau kualitas suatu sekolah berdasarkan nilai akreditasi tersebut benar-benar menggambarkan keadaan sebenarnya dari sekolah tersebut. Oleh karena itu, perlu dikaji tentang hubungan nilai akreditasi sekolah dengan kualitas sekolah. Lebih lanjut perlu diketahui hubungan antara akreditasi sekolah dengan kinerja sekolah.

Berdasarkan latar belakang masalah di atas, dirumuskan masalah sebagai berikut:

1. Bagaimanakah hubungan pelaksanaan akreditasi sekolah dengan penjaminan mutu pendidikan?

2. Sejauh mana dampak akreditasi sekolah terhadap peningkatan kinerja sekolah?

\section{Tinjauan Pustaka}

Akreditasi adalah kegiatan penilaian kelayakan program dalam satuan pendidikan berdasarkan kriteria yang telah ditetapkan. Akreditasi sekolah merupakan kegiatan penilaian yang dilakukan oleh pemerintah dan/atau lembaga mandiri yang berwenang untuk menentukan kelayakan program dan/atau satuan pendidikan pada jalur pendidikan formal dan nonformal pada setiap jenjang dan jenis pendidikan, berdasarkan kriteria yang telah ditetapkan, sebagai bentuk akuntabilitas publik yang dilakukan secara objektif, adil, transparan, dan komprehensif dengan menggunakan instrumen dan kriteria yang mengacu kepada Standar Nasional Pendidikan.

Akreditasi adalah proses penilaian dengan indikator tertentu berbasis fakta. Asesor melakukan pengamatan dan penilaian sesuai realitas, tanpa ada manipulasi (Asmani, 2011: 184). Akreditasi dilakukan dengan tujuan untuk memperoleh gambaran keadaan kinerja 
madrasah dalam menyelenggarakan pendidikan, sebagai dasar yang dapat digunakan sebagai alat pembinaan dan pengembangan dalam rangka peningkatan mutu pendidikan di madrasah (Depag RI, 2008: 7).

Sekolah merupakan suatu lembaga atau tempat untuk belajar seperti membaca, menulis dan belajar untuk berperilaku yang baik. Sekolah juga merupakan bagian intergal dari suatu masyarakat yang berhadapan dengan kondisi nyata yang terdapat dalam masyarakat pada masa sekarang. Sekolah juga merupakan lingkungan kedua tempat anak-anak berlatih dan menumbuhkan kepribadiannya.Sekolah yang terakreditasi meliputi Taman Kanak-kanak (TK), Sekolah Dasar (SD), Sekolah Luar Biasa (SLB), Sekolah Lanjutan Tingkat Pertama (SLTP), Sekolah Menengah Umum (SMU), dan Sekolah Menengah Kejuruan (Arikunto, 1988: 20).

Mutu merupakan suatu konsep dalam manajemen mutu. Manajemen mutu merupakan suatu cara dalam mengelola suatu organisasi yang bersifat komprehensif dan terintegrasi yang diarahkan dalam rangka memenuhi kebutuhan pelanggan secara konsisten dan mencapai peningkatan secara terus menerus dalam setiap aspek kegiatan organisasi (Tenner dan De toro dalam Ali, 2007: 626).

\section{Metodologi Penelitian}

Metode yang digunakan di dalam penelitian ini adalah metode analisis kritis dan metode kepustakaan. Metode analisis kritis yang penulis maksudkan di sini adalah upaya menyeleksi dengan cara merangkum dan mempertimbangkan masalah sehingga dapat direduksi, direposisi, dan dipaparkan secara sistematis.

Sementara itu, metode kepustakaan adalah sebuah metode penelitian yang dilakukan dengan cara mengumpulkan, membaca, mencatat data pustaka serta mengolah bahan penelitian (Mustika, 2008: 3).

\section{Hasil Dan Pembahasan \\ Akreditasi Sekolah}

Akreditasi adalah kegiatan penilaian kelayakan program dalam satuan pendidikan berdasarkan kriteria yang telah ditetapkan. Akreditasi sekolah merupakan kegiatan penilaian yang dilakukan oleh pemerintah dan/atau lembaga mandiri yang berwenang untuk menentukan kelayakan program dan/atau satuan pendidikan pada jalur pendidikan formal dan nonformal pada setiap jenjang dan jenis pendidikan, berdasarkan kriteria yang telah ditetapkan, sebagai bentuk akuntabilitas publik yang dilakukan secara objektif, adil, transparan, dan komprehensif dengan menggunakan instrumen dan kriteria yang mengacu kepada Standar Nasional Pendidikan.

Menurut Permendikbud No. 59 tahun 2012, bahwa Badan Akreditasi Nasional Sekolah Madrasah (BAN-SM) merupakan badan mandiri yang menetapkan kelayakan suatu program dan atau satuan pendidikan jenjangpendidikan dasar dan menengah jalur formal dengan mengacu Standar Nasional Pendidikan (SNP).

Akreditasi sekolah juga diartikan sebagai proses penilaiaian secara komprehensif terhadap kelayakan dan kinerja satuan dan/atau program pendidikan, yang dilakukan sebagai bentuk akuntabilitas publik. Akuntabilitas publik ini merupakan suatu bentuk pertanggungjawaban sekolah kepada publik, apakah layanan yang dilaksanakan dan diberikan oleh sekolah telah memenuhi harapan atau keinginan masyarakat.

Dari beberapa pengertian di atas, dapat disimpulkan bahwa akreditasi sekolah merupakan suatu proses penilaian secara komprehensif terhadap kelayakan suatu program pendidikan 
dengan mengacu Standar Nasional Pendidikan (SNP) yang dilakukan sebagai bentuk akuntabilitas publik.

Berkaitan dengan pelaksanaan akreditasi ini, pemerintah telah menetapkan Badan Akreditasi Sekolah/Madrasah (BAN-S/M) sebagai badan evaluasi mandiri yang menetapkan kelayakan program dan/atau satuan pendidikan dasar dan menengah jalur formal dengan mengacu pada standar nasional pendidikan. Dengan kebijaksanaan ini diharapkan pelaksanaan akreditasi sekolah/madrasah dapat dilakukan secara objektif, adil, profesional, komprehensif, dan transparan sebagai bentuk akuntabilitas publik.

Dasar hukum pelaksanaan akreditasi sekolah adalah sebagai berikut :

1. Undang-undang No. 20 tahun 2003 tentang Sistem Pendidikan Nasional, Bab XVI Bagian Kedua pasal 60 tentang Akreditasi.

2. Peraturan Pemerintah No. 19 tahun 2005 tentang Standar Nasional Pendidikan pasal 86 dan 87.

3. Keputusan Menteri Pendidikan Nasional nomor: 087/U/2002 tahun 2002 tentang akreditasi sekolah.

4. Keputusan Menteri Pendidikan Nasional nomor: 039/O/2003 tentang pembentukan Badan Akreditasi Sekolah Nasional (BASNAS) yang bertugas menetapkan berbagai kebijakan yang terkait dengan pelaksanakan akreditasi sekolah.

Adapun tujuan dari akreditasi sekolah sesuai dengan Keputusan Menteri Pendidikan Nasional nomor: 087/U/2002 tahun 2002 adalah:

1. Untuk memperoleh gambaran kinerja sekolah yang dapat dipergunakan sebagai alat pembinaan, pengembangan, dan peningkatan mutu pendidikan.

2. Untuk menentukan tingkat kelayakan suatu sekolah dalam penyelenggaraan pelayanan pendidikan.

Sedangkan fungsi dari akreditasi sekolah adalah sebagai berikut:

1. Untuk pengetahuan, yaitu dalam rangka mengetahui bagaimana kelayakan dan kinerja sekolah dilihat dari berbagai unsur yang terkait yang mengacu pada kualitas yang dikembangkan berdasarkan indikator-indikator tertentu.

2. Untuk akuntabilitas, yaitu agar sekolah dapat mempertanggungjawabkan apakah layanan yang diberikan memenuhi harapan atau keinginan masyarakat.

3. Untuk kepentingan pengembangan, yaitu agar sekolah dapat melakukan peningkatan kualitas atau pengembangan berdasarkan masukan dari hasil akreditasi.

Sesuai dengan Keputusan Menteri Pendidikan Nasional nomor: 087/U/2002 tahun 2002, pelaksanaan akreditasi sekolah mengikuti alur sebagai berikut:

1. Penyusunan rencana jumlah dan alokasi sekolah/madrasah

2. Pengumuman secara terbuka kepada sekolah/madrasah

3. Pengusulan daftar sekolah/madrasah

4. Pengiriman perangkat akreditasi ke sekolah/madrasah

5. BAP-S/M mengirimkan perangkat akreditasike sekolah/madrasah yang terdiri dari:

a. Instrumen Akreditasi

b. Petunjuk Teknis Pengisian Instrumen Akreditasi

c. Instrumen Pengumpulan Data dan Informasi Pendukung

d. Teknik Penskoran dan Pemeringkatan Hasil Akreditasi

6. Pengisian instrumen akreditasi dan instrumen pengumpulan data

7. Informasi pendukung

8. Pengiriman hasil isian instrumen akreditasi dan instrumen

9. Pengumpulan data dan informasi pendukung ke bap-s/m

10. Penentuan kelayakan visitasi 
11. Penugasan tim asesor

12. Pelaksanaan visitasi

13. Verifikasi hasil visitasi

14. Penetapan hasil akreditasi sekolah/madrasah

15. Penerbitan sertifikat

Pelaksanaan akreditasi sekolah/madrasah memiliki manfaat sebagai berikut:

1. Dapat dijadikan sebagai acuan dalam upaya peningkatan mutu Sekolah/Madrasah dan rencana pengembangan Sekolah/Madrasah.

2. Dapat dijadikan sebagai motivator agar Sekolah/Madrasah terus meningkatkan mutu pendidikan secara bertahap, terencana, dan kompetitif baik di tingkat kabupaten/kota, provinsi, nasional bahkan regional dan internasional.

3. Dapat dijadikan umpan balik dalam usaha pemberdayaan dan pengembangan kinerja warga Sekolah/Madrasah dalam rangka menerapkan visi, misi, tujuan, sasaran, strategi dan program Sekolah/Madrasah.

4. Membantu mengidentifikasi Sekolah/Madrasah dan program dalam rangka pemberian bantuan pemerintah, investasi dana swasta dan donatur atau bentuk bantuan lainnya.

5. Bahan informasi bagi Sekolah/Madrasah sebagai masyarakat belajar untuk meningkatkan dukungan dari pemerintah, masyarakat, maupun sektor swasta dalam hal profesionalisme, moral, tenaga dan dana.

6. Membantu Sekolah/Madrasah dalam menentukan dan mempermudah kepindahan peserta didik dari satu sekolah ke sekolah lain, pertukaran guru dan kerjasama yang saling menguntungkan.

Adapun prinsip-prinsip yang dijadikan pijakan dalam melaksanakan akreditasi sekolah/ madrasah adalah sebagai berikut.

1. Objektif

Akreditasi sekolah / madrasah pada hakikatnya merupakan kegiatan penilaian tentang kelayakan penyelenggaraan pendidikan yang ditunjukkan oleh suatu sekolah/madrasah. Dalam pelaksanaan penilaian ini berbagai aspek yang terkait dengan kelayakan itu diperiksa dengan jelas dan benar untuk memperoleh informasi tentang keberadaannya.

2. Komprehensif

Dalam pelaksanaan akreditasi sekolah/madrasah, fokus penilaian tidak hanya terbatas pada aspek-aspek tertentu saja tetapi juga meliputi berbagai komponen pendidikan yang bersifat menyeluruh.

3. Adil

Dalam melaksanakan akreditasi, semua sekolah/madrasah harus diperlakukan sama dengan tidak membedakan sekolah/madrasah atas dasar kultur, keyakinan, sosial budaya, dan tidak memandang status sekolah/madrasah baik negeri ataupun swasta.

4. Transparan

Data dan informasi yang berkaitan dengan pelaksanaan akreditasi sekolah/madrasah seperti kriteria, mekanisme kerja, jadwal serta sistem penilaian akreditasi dan lainnya harus disampaikan secara terbuka dan dapat diakses oleh siapa saja yang memerlukannya.

5. Akuntabel

Pelaksanaan akreditasi sekolah / madrasah harus dapat dipertanggungjawabkan baik dari sisi penilaian maupun keputusannya sesuai dengan aturan dan prosedur yang telah ditetapkan.

6. Profesional

Pelaksanaan akreditasi sekolah / madrasah dilakukan oleh orang-orang yang memiliki kompetensi dan integritas yang tinggi di bidang akreditasi.

Akreditasi dilaksanakan melalui prosedur sebagai berikut:

1. pengajuan permohonan akreditasi dari sekolah; 
2. evaluasi diri oleh sekolah;

3. pengolahan hasil evaluasi diri;

4. visitasi oleh asesor;

5. penetapan hasil akreditasi;

6. penerbitan sertifikat dan laporan akreditasi.

Pihak-pihak yang terlibat dalam sistem akreditasi meliputi:

1. Badan Akreditasi Nasional Sekolah / Madrasah (BAN-S/M)

2. Badan Akreditasi Provinsi Sekolah/Madrasah (BAP-S/M)

Pelaksanaan akreditasi pada dasarnya dilakukan pada tingkat sekolah/madrasah oleh BAN-S/M. Dalam pelaksanaan akreditasi tersebut BAN-S/M dibantu BAP-S/M, sesuai Permendiknas Nomor 29 Tahun 2005. Untuk keperluan tersebut, maka dibentuk BAPS/M pada setiap provinsi.

3. Unit Pelakasana Akreditasi Sekolah / Madrasah (UPA-S/M) UPA-S/M bertugas membantu BAP-S/M

4. Asesor

Asesor adalah tenaga profesional yang telah memenuhi persyaratan untuk diangkat dan ditugasi oleh BAN-S/M sebagai lembaga akreditasi untuk melakukan penilaian dan visitasi di sekolah/madrasah sebagai bagian dari proses akreditasi.

5. Sekolah/Madrasah

Akreditasi sekolah/ madrasah dilaksanakan oleh suatu badan non struktural yang dibentuk pemerintah, bersifat mandiri serta bertanggungjawab kepada Menteri Pendidikan Nasional. Kelembagaan akreditasi terdiri dari Badan Akreditasi Nasional Sekolah/Madrasah (BANS/M) dan Badan Akreditasi Provinsi Sekolah/Madrasah (BAP-S/M). Apabila diperlukan BAP-SM dapat membentuk Unit Pelaksana Akreditasi Sekolah / Madrasah (UPA-S/M) Kabupaten / Kota. Struktur organisasi lembaga akreditasi sekolah/madrasah seperti ditunjukkan pada diagram Gambar berikut.

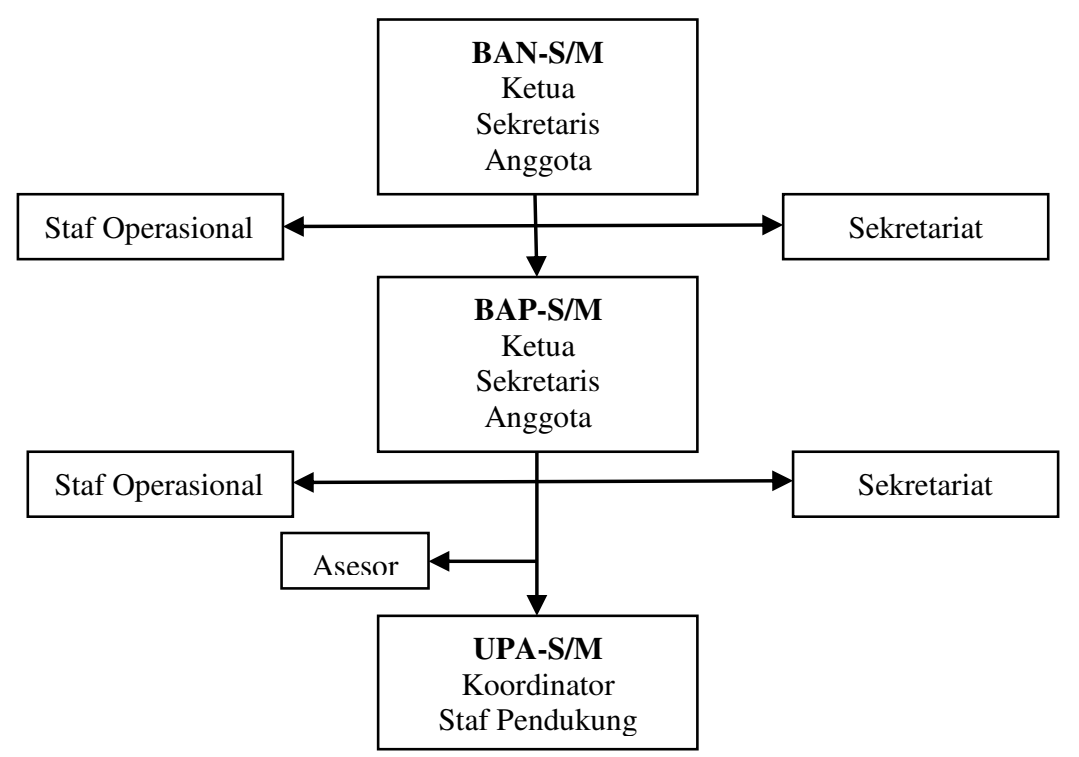

Gambar 1. Struktur Organisasi BAN S/M 
Adapun tingkat dan kewenangan Badan Akreditasi Sekolah/Madrasah adalah sebagai berikut: (1) badan Akreditasi Nasional-Sekolah/Madrasah (BAN-S/M); merumuskan kebijakan operasional, melakukan sosialisasi kebijakan dan melaksanakan akreditasi S/M. (2) badan Akreditasi Propinsi-Sekolah/Madrasah (BAP-S/M); melaksanakan akreditasi untuk TK/RA, SD/MI, SMP/MTs, SMA/MA, SMK/MAK dan SLB. (3) unit Pelaksana Akreditasi (UPA)-Kabupaten/Kota; membantu BAP-S/M melaksanakan akreditasi.

Badan Akreditasi Nasional-Sekolah/Madrasah (BAN S/M) berfungsi: (1) merumuskan kebijakan dan menetapkan akreditasi Sekolah/Madrasah. (2) merumuskan kriteria dan perangkat akreditasi Sekolah/Madrasah untuk diusulkan kepada Menteri. (3) melaksanakan sosialisasi kebijakan, kriteria dan perangkat akreditasi Sekolah/Madrasah. (4) melaksanakan dan mengevaluasi pelaksanaan akreditasi Sekolah/Madrasah. (5) memberikan rekomendasi tindak lanjut hasil akreditasi. (6) mengumumkan hasil akreditasi Sekolah/Madrasah secara nasional. (7) melaporkan hasil akreditasi Sekolah/Madrasah kepada Menteri. (8) melaksanakan ketatausahaan BAN-S/M.

Badan Akreditasi Propinsi-Sekolah/Madrasah (BAP-S/M) bertugas: (1) melakukan sosialisasi kebijakan dan pencitraan BAN-S/M dan BAP-S/M kepada Pemprov, Kanwil Kemenag, KanKemenag, Sekolah/Madrasah, dan masyarakat pendidikan pada umumnya. (2) merencanakan program akreditasi Sekolah/Madrasah yang menjadi sasaran akreditasi. (3) mengadakan pelatihan asesor sesuai dengan pedoman yang ditetapkan oleh BAN-S/M. (4) menetapkan hasil peringkat akreditasi melalui Rapat Pleno Anggota BAP-S/M. (5) menyampaikan laporan pelaksanaan program dan pelaksanaan akreditasi serta rekomendasi tindak lanjut kepada BAN-S/M dengan tembusan kepada Gubernur. (6) menyampaikan laporan hasil akreditasi dan rekomendasi tindak lanjut kepada Dinas Pendidikan Provinsi, Kanwil Kemenag dan LPMP. (7) menyampaikan laporan hasil akreditasi dan rekomendasi tindak lanjut kepada Pemerintah Kab/Kota yang bersangkutan dan satuan pendidikan dalam rangka penjaminan mutu sesuai lingkup kewenangan masing-masing. (8) mengumumkan hasil akreditasi kepada masyarakat, baik melalui pengumuman maupun media massa. (9) mengelola sistem basis data akreditasi. (10) melakukan monitoring dan evaluasi secara terjadwal terhadap kegiatan akreditasi. (11) melaksanakan kesekretariatan BAP-S/M. (12) membuat tugas pokok dan fungsi sesuai dengan kerangka tugas pokok BAP-S/M. (13) melaksanakan tugas lain sesuai kebijakan BAN-S/M.

Tugas Unit Pelaksana Akreditasi (UPA) Kabupaten/Kota adalah: (1) Sebagai penghubung antara BAP-S/M dengan Dinas Pendidikan dan Kankemenag, (2) mengusulkan jumlah Sekolah/Madrasah yang akan diakreditasi kepada BAP-S/M. (3) mengusulkan jumlah asesor yang dibutuhkan untuk kab/kota yang bersangkutan. (4) menyusun data Sekolah/Madrasah yang telah dan akan diakreditasi di tingkat kabupaten/kota. (5) mengkoordinasikan sasaran penugasan asesor. (6) mengkoordinasikan jadwal pemberangkatan asesor. (7) menyiapkan perangkat akreditasi dan administrasi bagi asesor. (8) melaporkan pelaksanaan kegiatan. (9) membantu administrasi BAP-S/M. (10) melaksanakan tugas lain yang ditetapkan oleh BAPS/M.

\section{Penjaminan Mutu Pendidikan}

Mutu merupakan suatu konsep dalam manajemen mutu. Manajemen mutu merupakan suatu cara dalam mengelola suatu organisasi yang bersifat komprehensif dan terintegrasi yang diarahkan dalam rangka memenuhi kebutuhan pelanggan secara konsisten dan mencapai peningkatan secara terus menerus dalam setiap aspek kegiatan organisasi (Tenner dan De toro dalam Ali, 2007: 626).

Penjaminan dan peningkatan mutu pendidikan pendidikan dasar dan menengah merupakan tanggung jawab satuan pendidikan yang harus didukung oleh pemerintah daerah Provinsi 
dan Kabupaten/Kota sesuai dengan kewenangan masing-masing serta peran masyarakat. Pada level pemerintah pusat penjaminan dan peningkatan mutu pendidikan pendidikan dasar dan menengah dilaksanakan oleh Kementerian Pendidikan dan Kebudayaan melalui Direktorat Jenderal Pendidikan Dasar dan Menengah, Kementerian Agama, dan Kementerian Dalam Negeri serta instansi terkait lainnya. Pada level daerah Provinsi, LPMP dan Kantor Wilayah Departemen Agama, sedangkan pada level pemerintah daerah Kabupaten /Kota dilaksanakan oleh Dinas Pendidikan Kabupaten/Kota dan Kantor Departemen Agama Kabupaten/Kota.

Tujuan penjaminan mutu pendidikan dibedakan menjadi dua, yaitu tujuan akhir dan tujuan antara. Tujuan akhir penjaminan mutu pendidikan adalah tingginya kecerdasan kehidupan manusia dan bangsa sebagaimana dicita-citakan oleh Pembukaan Undang-undang Dasar Negara Republik Indonesia tahun 1945 yang dicapai melalui penerapan SPMP. Sedangkan tujuan antara yang hendak dicapai melalui penjaminan mutu pendidikan adalah terbangunnya SPMP yang meliputi:

1. Terbangunnya budaya mutu pendidikan formal, nonformal, dan atau informal.

2. Pembagian tugas dan tanggungjawab yang jelas dan proporsional dalam penjaminan mutu pendidikan formal dan/atau nonformal pada satuan atau program pendidikan, penyelenggara satuan atau program pendidikan, pemerintah kabupaten atau kota, pemerintah provinsi, dan pemerintah.

3. Ditetapkannya secara nasional acuan mutu dalam penjaminan mutu pendidikan formal dan/atau nonformal.

4. Terpetakannya secara nasional mutu pendidikan formal dan nonformal yang dirinci menurut provinsi, kabupaten atau kota, dan satuan atau program pendidikan.

5. Terbangunnya sistem informasi mutu pendidikan formal dan nonformal berbasis teknologi informasi dan komunikasi yang andal, terpadu, dan tersambung yang menghubungkan satuan atau program pendidikan, penyelenggara satuan atau program pendidikan.

Penjaminan mutu pendidikan menganut paradigma:

1. Pendidikan untuk semua yang bersifat inklusif dan tidak mendiskriminasi peserta didik atas dasar latar belakang apa pun.

2. Pembelajaran sepanjang hayat berpusat pada peserta didik yang memperlakukan, memfasilitasi, dan mendorong peserta didik menjadi insan pembelajar mandiri yang kreatif, inovatif, dan berkewirausahaan.

3. Pendidikan untuk perkembangan, pengembangan, dan/atau pembangunan berkelanjutan (education for sustainable development), yaitu pendidikan yang mampu mengembangkan peserta didik menjadi rahmat bagi sekalian alam.

Penjaminan mutu pendidikan di atas dilakukan atas dasar prinsip-prinsip sebagai berikut:

1. keberlanjutan,

2. terencana dan sistematis,

3. menghormati otonomi satuan pendidikan formal dan nonformal,

4. memfasilitasi pembelajarn informal masyarakat berkelanjutan dengan regulasi negara yang minimal mungkin,

5. SPMP merupakan sistem terbuka yang harus disempurnakan secara berkelanjutan.

\section{Hubungan Antara Akreditasi Sekolah dengan Penjaminan Mutu pendidikan}

Berdasarkan uraian di atas, dapat dilihat adanya hubungan yang erat antara akreditasi sekolah dengan penjaminan mutu pendidikan. Sekolah yang akan melaksanakan akreditasi diberi waktu untuk mempersiapkan segala sesuatu yang diperlukan dalam akreditasi. Segala komponen dapat dipersiapkan terlebih dahulu, karena akreditasi meliputi delapan Standar Nasional Pendidikan (SNP), yaitu standar kompetensi lulusan, standar isi, standar proses, 
standar pengelolaan, standar pembiayaan, standar sarana prasarana, standar pendidik dan tenaga kependidikan, serta standar penilaian. Dalam rangka mempersiapkan 8 standar tersebut, secara langsung maupun tidak langsung semua komponen sekolah akan berbenah menyesuaikan dengan standar yang telah ditetapkan.

Sebelum pelaksanaan akreditasi, dua tahun sebelumnya sekolah mengajukan diri untuk diakreditasi. Dalam rentang waktu dua tahun itu pula, sekolah akan berusaha memenuhi kriteria-kriteria yang terdapat dalam instrumen akreditasi, misalnya dalam standar proses, semua guru harus membuat perangkat pembelajaran dan melaksanakan pembelajaran yang terstandar. Sekolah dengan bimbingan dari pengawas sekolah akan berusaha untuk memenuhi kriteria tersebut, sehingga mutu pembelajaran akan meningkat. Untuk standar penilaian, dalam instrumen tertulis peningkatan nilai ujian sekolah maupun ujian nasional selama dua tahun terakhir. Apabila nilai rata-rata ujian turun atau tidak naik, maka nilai yang diperoleh akan sedikit (dari skala 1-5). Oleh karena itu, sekolah pasti akan memacu peningkatan nilai ujian sekolah maupun ujian nasional yang pada akhirnya mutu pendidikan yang dilihat dari komponen nilai akan meningkat. Dengan demikian melalui pelaksanaan akreditasi sekolah akan dicapai mutu atau kualitas pendidikan yang diarahkan pada hal-hal sebagai berikut:

1. Proses akreditasi mengarah pada peningkatan kualitas sekolah.

2. Untuk melihat dan memperoleh gambaran kinerja sekolah yang sebenarnya.

3. Sebagai alat pembinaan, pengembangan, dan peningkatan mutu pendidikan di sekolah.

4. Sebagai gambaran kelayakan sekolah dalam penyelenggara pendidikan.

5. Memberikan gambaran menyeluruh bagi masyarakat tentang tingkatan suatu sekolah di antara sekolah-sekolah lainnya.

\section{Dampak Akreditasi Sekolah terhadap Peningkatan Kinerja Sekolah}

Dari uraian di atas, dapat dilihat adanya hubungan antara akreditasi sekolah dengan penjaminan mutu pendidikan. Pada kenyataannya selain hubungan tersebut, akreditasi sekolah memberikan dampak atau akibat tidak langsung terhadap kinerja sekolah. Sekolah dengan akreditasi A tentu saja akan berusaha mempertahankan peringkat tersebut. Semua komponen sekolah pasti tidak rela apabila peringkat sekolahnya turun menjadi B atau C. Untuk mempertahankan suatu prestasi memang lebih sulit daripada meraih suatu prestasi. Diperlukan kesungguhan dan upaya terus menerus agar prestasi yang sudah diraih tidak hilang begitu saja.

Akreditasi sekolah membawa dampak positif kepada seluruh warga sekolah, antara lain:

1. Tumbuhnya kesadaran dari seluruh warga sekolah untuk memberikan dan meningkatkan pelayanan sesuai dengan standar atau kriteria yang ditetapkan dalam proses akreditasi.

2. Meningkatnya kerjasama seluruh komponen sekolah untuk memberikan yang terbaik untuk sekolah.

Selain dampak positif, ada juga dampak negatif dari akreditasi sekolah terhadap kinerja sekolah, antara lain:

1. Peningkatan kinerja dari semua komponen sekolah hanya dilakukan menjelang pelaksanaan akreditasi sekolah, setelah selesai akan kembali seperti semula.

2. Ada sekolah yang melakukan rekayasa data untuk mencapai nilai akreditasi yang diharapkan.

\section{Simpulan dan Saran}

Simpulan

Berdasarkan pembahasan di atas, dapat disimpulkan bahwa pelaksanaan akreditasi sekolah adalah suatu upaya dari pemerintah untuk menjamin mutu pendidikan serta meningkatkan kinerja sekolah terutama dalam memberikan layanan pendidikan kepada masyarakat. 
Akreditasi Sekolah/madrasah bertujuan untuk memberikan informasi tentang kelayakan sekolah/madrasah atau program yang dilaksanakannya berdasarkan Standar Nasional Pendidikan, memberikan pengakuan peringkat kelayakan, serta memberikan rekomendasi tentang penjaminan mutu pendidikan kepada program dan atau satuan pendidikan yang diakreditasi. Terdapat dampak positif dan dampak negatif dari penyelenggaraan akreditasi sekolah. Hal tersebut sebaiknya menjadi koreksi bagi penyelenggara pendidikan untuk lebih meningkatkan sistem yang sudah dijalankan. Selanjutnya, pelaksanaan akreditasi diharapkan dapat mendorong atau menciptakan suasana kondusif bagi pertumbuhan pendidikan dan memberikan arahan untuk evaluasi diri yang berkelanjutan, serta sebagai perangsang untuk terus berusaha mencapai mutu yang diharapkan sehingga secara tidak langsung dapat menjamin mutu pendidikan.

\section{Saran}

Berdasarkan kesimpulan di atas, penulis dapat memberikan saran bahwa Akreditasi harus dilakukan melalui tindakan membandingkan kondisi sekolah dengan delapan kriteria (standar) yang telah ditetapkan agar dapat terlaksana dengan baik dan sesuai dengan apa yang diinginkan.

\section{Daftar Pustaka}

Ali, Muhammad. (2007). Ilmu dan Aplikasi Pendidikan, Bandung: Pedagogiana Press. Arikunto, Suharsimi. (1988). Penilaian Program Pendidikan. Jakarta: Bina Aksara.

Asmani, J. M. (2011). Tips Praktis Membangun dan Mengolah Administrasi. Jogjakarta: Diva Press.

Depag RI. (2008). Pedoman Akreditasi Madrasah. Direktoral Jenderal Kelembagaan Agama Islam.

Mustika, Z. (2008). Metode Penelitian Kepustakaan. Jakarta: Yayasan Obor Indonesia.

http://www.unesco.org/Education For All (EFA) Global Monitoring Report (2012): The Hidden Crisis, Armed Conflict and Education. (03/05/2014) 